\title{
The Review of the Impact of the Tax Incentive Policies and Fiscal Policies on R \& D at the Firm Level
}

\author{
Yafeng $\mathrm{Hu}^{1}$, Weiguang $\mathrm{Ju}^{2}, \mathrm{Ke} \mathrm{Gao}^{2}$ \\ ${ }^{1}$ School of China Academy of Public Finance and Public Policy, Central University of Finance and Economics, Beijing, P. R. China \\ ${ }^{2}$ Development Research Center of Shandong Provincial People's Government, Jinan, P. R. China \\ Email address: \\ 1023057500@qq.com (Yafeng Hu),gkfly@126.com (Ke Gao)
}

\section{To cite this article:}

Yafeng Hu, Weiguang Ju, KeGao. The Review of the Impact of the Tax Incentive Policies and Fiscal Policies on R \& D at the Firm Level. International Journal of Economics, Finance and Management Sciences. Vol. 7, No. 1, 2019, pp. 1-5. doi: 10.11648/j.ijefm.20190701.11

Received: December 10, 2018; Accepted: January 17, 2019; Published: February 1, 2019

\begin{abstract}
Based on the research and review of existing literature, this paper finds that the effects of government public policies (including fiscal policies and tax policies) on enterprise innovation can be roughly divided in to the following three categories. Firstly, the government's public policies are encouraging enterprise innovation. When companies are stimulated by public subsidies or tax incentives, they will increase investment in R \& D and innovation. Secondly, the government's public policy has inhibited enterprise innovation. When enterprises receive the public subsidies from the government or enjoy the related tax incentives, they often do not increase the investment in research and innovation, but simply reduce the investment on R \& D. Thirdly, there is no significant or non-linear relationship between government public policy and enterprise innovation. There is no significant correlation or complex non-linear relationship between whether enterprises increase their investment in R \& D innovation and the government's public subsidies and other policies. At the same time, the author found that most of the existing research samples are large enterprises in developed countries. Furthermore, there is a lack of relevant research on small and medium-sized enterprises in developing countries. SMEs account for the vast majority of the whole enterprises, so it is meaningful to study the impact of government subsidies and tax incentives on SMEs' innovation.
\end{abstract}

Keywords: Innovation, Fiscal and Tax Policies, Market Failure

\section{Introduction}

Enterprises are the main supply of social innovation. In the era of accelerating economic globalization, a country needs an endless source of innovation to maintain its sustainable competitiveness. Due to the spillover effect of innovation, enterprises are not willing to invest in innovation. At this time, the governments need to intervene in the market, and make policies to support enterprises to carry out innovation activities. But what is the justification for government intervention Or by the market itself? This paper attempts to find out whether the government should intervene in enterprise innovation through public policy through literature review and combing. It is found that there is no unified conclusion on the impact of government public policies on enterprise innovation. The possible reasons for this situation include enterprise heterogeneity, government subsidy "noise" and policy selection bias. This provides a reference for the government to formulate public policies and improve the efficiency of the use of public funds. In addition, there is a lack of literature on SMEs as research samples. This may be the area that future studies should focus on.

\section{Literature Review}

The academic research on the impact of fiscal policy and taxation policy on enterprises' innovation is mostly for large enterprises, and there is a lack of research on small and medium-sized enterprises. The existing relevant researches are divided into the following three categories: fiscal policies and tax credit policies promoting enterprise innovation; Fiscal policies and tax credit policies restraining enterprise innovation; no significant or nonlinear relationship between fiscal policies and tax incentive policies and enterprise innovation. The are as the following table 1. 
Table 1. Three types of public policy effect.

\begin{tabular}{ll}
\hline The Impact of the Tax Incentive Policies and Fiscal Policies on R \& D at the Firm Level & $\begin{array}{l}\text { Promoting effect on corporate innovation } \\
\text { Crowding-out effect on enterprise innovation } \\
\text { Other effects on business innovation }\end{array}$ \\
\hline
\end{tabular}

The first part is about the crowed effect of fiscal and taxation policies on the corporate innovation, including three different types. The first type of research focuses on a sample of American companies: the 1987 us government-funded semi-conductor technology innovation project, which aims to save the shrinking market share of 14 related companies. Irwin (1996) evaluated the effect of the government-funded project on R \& D expenditure, profitability and productivity of the funded enterprises. The results showed that the project reduced the total $\mathrm{R} \& \mathrm{D}$ expenditure of the funded enterprises by 300 million dollars per year, and the negative correlation between the government-funded projects and the R \& D of enterprises [1]. Similarly, Wallsten (2000) took the research on the effect of SBIR program in the United States on enterprise $\mathrm{R} \& \mathrm{D}$ activities as an example to evaluate the impact of government industrial $\mathrm{R} \& \mathrm{D}$ policies on private innovation. This paper also takes into account endogenous problems caused by government policy selection bias and uses instrumental variables. By using the SEM model, it can be found that enterprises with more employees and more R \& $\mathrm{D}$ experience are more likely to be funded. Government funding has completely crowed out private investment in research and development [2]. Mamuneas and Nadiri (1996) compared the impact of tax incentives and public R \& D funding on $\mathrm{R} \& \mathrm{D}$ investment of American enterprises. The empirical results show that: the public R \& D funding reduces the production cost of enterprises, but at the same time crowds out the private R \& D investment of enterprises; Tax credits, especially R \& D expense deduction policies, have significantly stimulated private $\mathrm{R} \& \mathrm{D}$ investment of enterprises. When public $\mathrm{R} \& \mathrm{D}$ funding and private $\mathrm{R} \& \mathrm{D}$ investment are invested in enterprises with low $R$ \& $D$ intensity, the substitution effect is strong. With the increase of $\mathrm{R} \& \mathrm{D}$ intensity, the substitution effect decreases. The incentive effect of tax credit policies is greatly weakened when the government regards R \& D expenditure as tangible asset investment [3].

Table 2. Research classification of the first part.

\begin{tabular}{ll}
\hline \multirow{3}{*}{ The first part (by samples) } & Enterprises from US \\
& Enterprises from other countries \\
& Enterprises across some countries \\
\hline
\end{tabular}

The second type of research focuses on samples of enterprises from another country other than the United States. For example, Gorg and Strobl (2006) studied the relationship between government's public R \& D funding and enterprises' private $\mathrm{R} \& \mathrm{D}$ input by using Irish manufacturing enterprise data. Enterprise samples are divided into three categories: total samples, domestic resident enterprises and foreign-funded enterprises. Considering the potential endogenous problems, DID-PSM was used to estimate samples. The empirical results showed that, for domestic resident enterprises, small-scale government subsidies stimulated private $\mathrm{R} \& \mathrm{D}$ expenditures of enterprises, while large-scale government subsidies to some extent crowed out private $\mathrm{R} \& \mathrm{D}$ expenditures of enterprises. For foreign-funded enterprises, the scale of government assistance has neither incentive nor crowding out effect on private R \& Dexpenditure. The author holds the view that the effect of public funding should focus on whether enterprises are encouraged to invest in private R \& D rather than all R \& D investment [4]. Yao and yu (2014) built an econometric model based on the production function, based on the questionnaire survey data of small and medium-sized enterprises in Guangdong province, and empirically tested the influence of different levels of subsidies on intellectual property rights of small and medium-sized enterprises in science and technology from the perspective of central government financial subsidies and local government financial subsidies. The results show that the central financial subsidies have no significant influence on the formation of intellectual property assets of small and medium-sized enterprises. Local financial subsidies have a significant positive correlation with the formation of intellectual property assets of small and medium-sized enterprises. Fiscal subsidies have a significant substitution effect on innovation and R \& D investment of small and medium-sized enterprises [5].

In the third type, the corporation samples come from different countries. Guellec and Pottelsberghe (2003) attempted to study the total net effect of government funding on $\mathrm{R} \& \mathrm{D}$ activities of enterprises in 17-member countries of OECD. Government appropriation, government procurement, tax incentives and scientific research innovation in public institutions and universities are common policies stimulating innovation. The main empirical results are as follows: direct government funding positively stimulates enterprise innovation (except for defense R \& D activities); Tax incentives have short-term, positive incentive effect; Stable direct allocation and tax incentives have stronger incentive effect over a period of time; When enterprises doubt the uncertainty of R \& D innovation results and the durability of government support, they will not carry out innovation activities. There is a mutual substitution effect between direct appropriation and preferential tax policies, that is, increasing the stimulus intensity of one will weaken the incentive effect of the other [6].

The second part: there is no significant relationship between fiscal and taxation policies and enterprise innovation or a complex nonlinear relationship. The first type of research has found an inverted u-shaped relationship between fiscal and taxation policies and enterprise innovation. Wang 
and li (2014) empirically tested the correlation between R \& $\mathrm{D}$ investment of small and medium-sized enterprises and government fiscal and tax credit policies with the data of small and medium-sized enterprises in the SME board of the Shenzhen stock exchange and the gem from 2010 to 2012. The econometric analysis shows that the indirect tax preferential policies have no significant contribution to the $\mathrm{R}$ $\& D$ intensity of enterprises. There is an inverted u-shaped relationship between the $\mathrm{R} \& \mathrm{D}$ investment intensity of enterprises and the credit policies of enterprise income tax, which is mainly caused by the change of tax substitution effect and income effect [7]. While Zhou and Wu (2017) indicated that the effect of government subsidies on small and medium-sized enterprises, they added the enterprise characteristic of enterprise risk level. Based on the SME board data of Shenzhen stock exchange, the empirical test shows that the government subsidy intensity does not have a simple linear effect on the technological innovation of enterprises, but a U-shaped effect. Government subsidies and the risk level of enterprises have a crowding effect on the scientific and technological innovation activities of small and medium-sized enterprises [8]. The risk level of enterprises has a significant positive effect on the scientific and technological innovation activities of private enterprises. Based on the above research, Lin (2013) analyzed the effect of fiscal and tax policies after controlling enterprise scale. He pointed out that China's income tax reform improved the innovation ability of enterprises from the direct and indirect perspectives by reducing the tax rate and deducting the $\mathrm{R} \&$ $\mathrm{D}$ expense. There was not a simple linear relationship between tax incentive intensity and enterprise innovation, but an inverted "U" shape. Compared with large enterprises, small and medium-sized enterprises can use the $R \& D$ expense deduction policy to obtain stronger incentives for technological innovation [9].

Table 3. Relationship Between Polices and Innovation.

\begin{tabular}{ll}
\hline The second part & $\begin{array}{l}\text { A complex nonlinear relationship } \\
\text { No significant relationship }\end{array}$ \\
\hline
\end{tabular}

The second type of research finds that there is no significant relationship between fiscal and taxation policies and enterprise innovation. Li (2017) pointed out that when analyzing the incentive effect of fiscal subsidy policies on $\mathrm{R}$ \& D investment of enterprises. The existing studies did not remove the "noise" of subsidies that were not related to innovation of enterprises, such as export earnings discount, social security subsidy and fiscal discount, which would affect the reference significance of conclusions. After removing these "noise" subsidies, the author founded that financial innovation subsidies did not play a role in encouraging enterprises to invest in innovation [10]. Taking small and medium-sized enterprises as samples, Zhang (2015) studied the impact of three forms of technology innovation funds for small and medium-sized enterprises, namely, free subsidy, loan discount and capital investment, on innovation of small and medium-sized enterprises. The empirical findings were as follows: innovation subsidy had no significant effect on enterprise innovation input. In areas where the protection of intellectual property rights was weaker, the innovation subsidy policy can improve the innovation of enterprises. The innovation subsidy policy of loan discount interest rate stimulated enterprise innovation significantly, while the innovation subsidy policies promoted enterprise innovation insignificantly. In Germany, government subsidies had no significant effect on R \& D input or patent output of enterprises, but enterprises' participation in cooperative innovation had significantly stimulated their innovation. Most existing literatures ignored the lag effect of public support policies on enterprise R \& D, and thus overestimated the policy effect [11]. Gonzalez (2008) divided the total growth effect of enterprise R \& D into two parts: enterprises' spontaneous innovation activities to maintain their market dominance, enterprises' passive participation in $\mathrm{R} \& \mathrm{D}$ activities caused by public support policies. Considering the continuous variable of support policy included in the propensity matching model, the bias-corrected matching estimator was used to find matching companies. Based on the data of Spanish manufacturing enterprises, empirical results showed that there was no substitution effect between public R \& D expenditure and private enterprise expenditure [12].

The third part: fiscal and taxation policies promote enterprise innovation. The first type is the research on the positive influence of national fiscal policies on enterprise innovation. Levy (1983) and Nadiri (1993) found that there was a positive correlation between government funding and enterprise R \& D [13] [14]. Enterprise R \& D can be divided into basic research and applied research. Robson (1993) pointed out that there was a significant positive correlation between government funding and enterprise basic research, and there was a short-term positive correlation with enterprise applied research. Falk (2004) used enterprise data for the first time to empirically test the effect of Australian federal R \& D support program on enterprise behavior, and the results showed that the federal R \& D support program enhanced the innovation ability and competitiveness of enterprises [15].

Table 4. The main structure of the third part.

\begin{tabular}{ll}
\hline Fiscal policies effect on enterprises innovation & Considering the endogeneity \\
& $\begin{array}{l}\text { Ignoring the endogeneity } \\
\text { Considering the endogeneity } \\
\text { Tax credit policies effect on enterprises innovation }\end{array}$ \\
\hline
\end{tabular}

The following studies took into account the possibility of endogeneity in the process of government financial policy 
selection to subsidize enterprises. Czarnitzki and Almus (2003) studied the average effect of total subsidies received by enterprises on enterprise innovation. The author believed that the number of staff and salary in the R \& D department of enterprises would cause selection bias on the selection of enterprises for subsidy. The endogeneity was controlled by the propensity matching score model. Empirical test showed that in east German enterprises, the R \& Dinvestment of the funded enterprises increased by about $4 \%$ compared with that of the non-funded enterprises [16]. Czarnitaki (2007) studied the role of cooperative innovation and government subsidies in the innovation's process of enterprises. Taking the participation of enterprises in cooperation and the acceptance of subsidies as the policy processing variables, and taking German and Finnish enterprises as samples, the propensity score matching estimation method was applied. The results showed that enterprise participation and cooperation had positive incentive effect on enterprise innovation [17]. Busom (2004) pointed out that one possible explanation for the inconsistency in the effect of R \& D innovation subsidy was the heterogeneity of the industry in which the enterprise was in. Such heterogeneity led to different probabilities of the enterprise participating in R \& D activities, that was, the existence of self-selection of samples. Based on the questionnaire survey data, this paper considered the endogeneity caused by policy selection bias and adopted the propensity matching score model (PSM). The empirical test showed that enterprise scale had a positive or insignificant effect on enterprises' participation in public R \& D funded projects [18]. Different industry characteristics and different levels of funding institutions have different impact on the probability of enterprise participation. Different from the previous study, which used PSM to solve endogenous problems, Toole (2007) used the instrumental variable method. The funded basic medical research and clinical medical research lacked the support of empirical results to stimulate the innovation of medical enterprises. He used both hospitalization rates per thousand people of different ages and mortality controlling policies to select for endogeneity. The empirical test found that there was a complementary effect between public funded basic medical research and clinical medical research and pharmaceutical $R$ \& D investment. Both types of research increased private investment [19]. Tommy (2009) studied the influence of "R $\&$ D" subsidies and "development" subsidies in Norway on private R \& D activities of enterprises. The empirical results showed that public subsidies had a positive incentive effect on $\mathrm{R} \& \mathrm{D}$ and innovation activities of enterprises. Basic research subsidies mainly stimulated private $R$ \& $D$ investment of enterprises by increasing R \& D expenditure. Market development subsidies replaced some private R \& D spending by reducing firms' investment in future development [20]. Based on panel data of OECD15 countries, Wolff and haler (2008) controlled endogeneity with lag terms of relevant variables, and found that government subsidies effectively stimulated R \& D activities [21]. The following research used some other methods to solve the endogeneity.
Lerner (1999) found through a special database that enterprises funded by SBIR were more likely to obtain venture capital than the control group, and there was a positive correlation between government-funded projects and enterprise innovation [22].

The second type of research is the incentive effect of tax credit policies on enterprise innovation. Cappelen (2012) used Skatte FUNN plan database to analyze the effect of the plan, and the results showed that the preferential tax policies of the plan stimulated the $\mathrm{R} \& \mathrm{D}$ process of new processes of enterprises, and to some extent stimulating the new products of Norwegian enterprises [23]. Czarnitzki (2011) divided the tax credit policies into the federal level and the provincial level, assessing the impact of the tax credit policies on the innovation activities of Canadian manufacturing enterprises. And he used the non-parametric matching model to analyze. The empirical results showed that tax incentives stimulate enterprise innovation output [24]. Berube (2009) pointed out that the existing literature mainly analyzed the incentive effect of a certain type of policies on enterprise R \& D. But there was no comparative study on the effect of different types of policies. Based on the questionnaire data of Canadian enterprises, this paper indicated that the innovation output between enterprises with both public R \& D funding and tax incentives and enterprises just enjoying tax incentives. Empirical analysis showed that enterprises with public funding and tax credit policies produced more innovative products than those that only received tax incentives [25].

\section{Conclusion and Suggestion}

In short, the researchers have not reached an agreement on the effect of government fiscal and tax policies on enterprise innovation. The possible reasons are as follows. Firstly, there is "noise" in the variables, such as financial subsidies unrelated to enterprise innovation. In order to acquire the unbiased outcome, the "noise" should be removed from the study. Secondly, without considering the policy selection bias, the endogeneity generated from this will lead to the bias of estimation results. Thirdly, the heterogeneity of enterprises, such as the country, industry and other factors may lead to differences in the results. In addition, it is worth noting that most literatures focus on large enterprises, or the whole enterprise samples, and lack studies on samples of small and medium-sized enterprises.

\section{References}

[1] Douglas A. Irwin, Peter J. Klenow, High-tech R \& D subsidies Estimating the effects of Sematech, Journal of International Economics, Volume 40, Issues 3-4, 1996, 323-344.

[2] Wallsten, S. J. (2000). "The Effects of Government-Industry R \& D Programs on Private R \& D: The Case of the Small Business Innovation Research Program." The RAND Journal of Economics 31 (1): 82-100. 
[3] Theofanis P. Mamuneas, M. IshaqNadiri, Public R \& D policies and cost behavior of the US manufacturing industries, Journal of Public Economics, Volume 63, Issue 1, 1996, Pages $57-81$

[4] Holger Görg, Eric Strobl, Do Government Subsidies Stimulate Training Expenditure? Micro econometric Evidence from Plant-Level Data.

[5] Southern Economic Journal Vol. 72, No. 4 (Apr., 2006), pp. 860-876.

[6] Guellec, D. and B. Van Pottelsberghe De La Potterie (2003). "The impact of public R \& D expenditure on business R \& D." Economics of Innovation and New Technology 12 (3): 225-243.

[7] Wang Min, Li Liang. (2014). Research on the Effect of Tax Preferential Policies to Incentivize SMEs' Technological Innovation. Statistics \& Decision. (24):170-173.

[8] Zhou Ming, Wu Cuiqing. (2017). The influence of government subsidies on small and medium - sized enterprise technology innovation. Science $R$ research Management 38 (S1):574-580.

[9] LIN Zhou-yu, LIN Han-chuan, et al (2013) Corporate Income Tax Reform and Technological Innovation of Chinese Firms. China Industrial Economics (03):111-123.

[10] LI Wangfu, DU jing, et al (2017). Do R \& D Subsidies R eally Stimulate Firms' R \& D Self - financing Investment: New Evidence from China's Listed Firms. Journal of Financial Research (10):130-145.

[11] Zhang Jie, Chen Zhiyuan, et al. (2015). On Evaluating China's Innovation Subsidy policy: Theory and Evidence. Economic Research Journal 50 (10):4-17+33.

[12] González, X. and C. Pazó (2008). "Do public subsidies stimulate private R \& D spending?" Research Policy 37 (3): 371-389.

[13] David M. Levy, Nestor E. Terleckyj, Effects of Government R \& D on Private R \& D Investment and Productivity: A Macroeconomic Analysis. The Bell Journal of Economics, Vol. 14, No. 2 (Autumn, 1983), pp. 551-561.

[14] Nadiri, M. Ishaq. "Innovations and Technological Spillovers." National Bureau of Economic Research Working Paper Series No. 4423 (1993).
[15] Falk, Rahel. "Measuring the Effects of Public Support Schemes on Firms' Innovation Activities: Survey Evidence from Austria." Research Policy 36, no. 5 (2007/06/01/ 2007): 665-79.

[16] Almus, M. and D. Czarnitzki (2003). "The Effects of Public R \& D Subsidies on Firms' Innovation Activities." Journal of Business \& Economic Statistics 21 (2): 226-236.

[17] Czarnitzki, Dirk, Bernd Ebersberger, and Andreas Fier. "The Relationship between R \& D Collaboration, Subsidies and R \& D Performance: Empirical Evidence from Finland and Germany." Journal of Applied Econometrics 22, no. 7 (2007/12/01 2007): 1347-66.

[18] Blanes, J. V. and I. Busom (2004). "Who participates in R \& D subsidy programs? The case of Spanish manufacturing firms." Research Policy 33 (10): 1459-1476.

[19] Andrew A. Toole (2007). "Does Public Scientific Research Complement Private Investment in Research and Development in the Pharmaceutical Industry?" The Journal of Law and Economics 50 (1): 81-104.

[20] Clausen, T. H. (2009). "Do subsidies have positive impacts on R \& D and innovation activities at the firm level?" Structural Change and Economic Dynamics 20 (4): 239-253.

[21] Wolff, G. B. and V. Reinthaler (2008). "The effectiveness of subsidies revisited: Accounting for wage and employment effects in business R \& D." Research Policy 37 (8): 1403-1412.

[22] Lerner, Josh, and Julie Wulf. "Innovation and Incentives: Evidence from Corporate R \& D." The Review of Economics and Statistics 89, no. 4 (2007/11/01 2007): 634-44.

[23] Cappelen, Å., A. Raknerud, et al. (2012). "The effects of R \& $\mathrm{D}$ tax credits on patenting and innovations." Research Policy 41 (2): 334-345.

[24] Czarnitzki, D., P. Hanel, et al. (2011). "Evaluating the impact of R \& D tax credits on innovation: A micro econometric study on Canadian firms." Research Policy 40 (2): 217-229.

[25] Charles, B. and M. Pierre (2009). "Are firms that receive R \& D subsidies more innovative?" Canadian Journal of Economics/Revue canadienned' économique 42 (1): 206-225. 